\title{
Inhibition of browning problem during the callogenesis of Spartium junceum $\mathrm{L}$.
}

\author{
Mina Taghizadeh $^{{ }^{*}}$ (]), Mahboubeh Ganji Dastjerdi ${ }^{1}$ (1) \\ ${ }^{1}$ Faculty of Agriculture and Natural Resources, Department of Horticultural Engineering, Arak University, Arak, Iran.
}

\begin{abstract}
During different phases of in vitro culture, plant tissues may be exposed to some stresses that never encounter in their natural habitats. The most significant stresses which interfere with in vitro culture are pathogenic contamination and browning disorder. Since browning sign is occurred during all phases of in vitro culture of Spartium junceum L., the present study was done preventing explants from browning during disinfection and callogenesis phases using exposure time of sterilants (ethanol 0, 30, 60 s and home bleach 0, 10, $15 \mathrm{~min}$ ), antioxidant compounds (PVP 0.5\%, Activated charcoal 0.1\%, Curcumin 0.1\%), Running water (30 and 60 $\mathrm{min}$ ) plant growth regulators (2,4-D 0, 0.5, 1 and $2 \mathrm{mg} \mathrm{L}^{-1}$ and BA $0,0.1$ and $0.2 \mathrm{mg} \mathrm{L}^{-1}$ ), and by changing light/dark conditions was designed. The results showed that ethanol $70 \%$ (30 s) in combination with home bleach $20 \%$ (10 min) had the best effect in control contaminations and browning sign in nodal explants of $S$. junceum. The application of PVP $0.5 \%$ in medium was the best treatment to control of browning nodal explants in callus induction phase. The highest callus formation and the lowest explant browning were obtained on the medium supplemented with $0.5 \mathrm{mg} \mathrm{L}^{-1}$ 2,4-D under the darkness condition. According to the results of this study, how disinfection methods, culture medium compositions and light conditions were effective on the browning and callogenesis of Spartium junceum L.
\end{abstract}

Keywords: callus, disinfection, explant, PVP, woody plant.

\section{Resumo}

Inibição do escurecimento durante a calogênese de Spartium junceum $\mathrm{L}$.

Durante as diferentes fases da cultura in vitro, os tecidos vegetais podem ser expostos a estresses que nunca ocorrem em seus habitats naturais. Os estresses mais significativos que interferem na cultura in vitro são a contaminação patogênica e o distúrbio de escurecimento. Como o sinal de escurecimento ocorre durante todas as fases da cultura in vitro de Spartium junceum L., o presente estudo foi realizado evitando o escurecimento dos explantes durante as fases de desinfecção e calogênese usando o tempo de exposição dos esterilizantes (etanol 0,30, 60 e água sanitária $0,10,15 \mathrm{~min}$ ), compostos antioxidantes (PVP $0,5 \%$, carvão ativado $0,1 \%$, Curcumina $0,1 \%$ ), água corrente (30 e $60 \mathrm{~min})$, reguladores de crescimento de plantas $\left(0,0,5,1\right.$ e $22,4-\mathrm{D} \mathrm{mg} \mathrm{L} \mathrm{L}^{-1}$ e $0,0,1 \mathrm{e}$ $0,2 \mathrm{BA} \mathrm{mg} \mathrm{L}^{-1}$ ), e alterando as condições de claro/escuro. Os resultados mostraram que o etanol 70\% (30 s) em combinação com alvejante caseiro $20 \%$ (10 $\mathrm{min}$ ) teve o melhor efeito no controle de contaminações e sinal de escurecimento em explantes nodais de S. junceum. A aplicação de PVP 0,5\% em meio foi o melhor tratamento para controle de explantes nodais de escurecimento na fase de indução de calo. A maior formação de calo e o menor escurecimento do explante foram obtidos no meio suplementado com 0,5 $\mathrm{mg} \mathrm{L}^{-1}$ 2,4-D no escuro. De acordo com os resultados deste estudo, como os métodos de desinfecção, composições do meio de cultura e condições de luz foram eficazes no escurecimento e calogênese de Spartium junceum L.

Palavras-chave: calo, desinfecção, explante, PVP, planta lenhosa.

\section{Introduction}

During different phases of in vitro culture, plant tissues may be exposed to some stresses that never encounter in their natural habitats. The most significant stresses which interfere with in vitro culture include plant pathogens contamination and browning (Taghizadeh et al., 2016). Browning disorder is often occurred in plant species containing high level of tannin and other hydroxid phenols. The wound due to cutting of tissue from stock plants induces polyphenol oxidase enzyme production which is crucial contributor to the oxidation of phenolic compounds, and

*Corresponding author: m-taghizadeh@araku.ac.ir 
accordingly makes tissues and culture medium brown and inhibits the explants growth or loss them (Meziani et al., 2016). One of the too serious difficulties in micropropagation process is in vitro pathogens; they cause infection and so loss the tissue culture process at early stages, even though sterilization methods are applied (Al Ghasheem et al., 2018). Therefore, the first step to start the tissue culture process involves disinfection and sterilization. There are a number of substances with mentioned property including variety of fungicides and antibiotics, sodium hypochlorite, calcium hypochlorite, ethyl alcohol, silver nitrate, mercury chloride, etc. (Ranjan et al., 2017). Among these, mercury chloride and silver nitrate have more powerful effects than others and have been applied frequently in past. Both mercury chloride and silver nitrate are of heavy metals group and have high reactivity to proteins which gives rise to block cell metabolism. Sodium hypochlorite and calcium hypochlorite make explants less injured because of their lower activity degree. However, they are able to induce necrotic explant and cell death in high concentration, and so cause browning of explants (Mahmoud and Al-Ani, 2016). In order to reduce browning degree, a number of approaches have been suggested (Krishna et al., 2008; Momeni et al., 2017).

Spartium junceum L. is a tall shrub-like ornamental plant from family Fabaceae. It has a characteristic specific to xerophilous plants (Gavilán et al., 2016). In vitro studies so far carry out on Spartium junceum L. involve in vitro culture the rooted micropropagated plantlet with the purpose of providing mycorhizal symbiosis via inoculating explant by Arbuscular mycorhiza during ex-vitro compatibility. Also, in order to investigate isoflavone compounds, the stem and nodal segments with axillary buds were cultured on medium MS containing $0.5 \mathrm{mg} \mathrm{L}^{-1} \mathrm{BA}$. After one month, shoot proliferation was found (Clematisa et al., 2014). Since browning disorder is occurred during all phases of in vitro culture of $S$. junceum and causes plant material to be lose, the present study was done with the purpose of control and preventing explants from browning during disinfection and Callogenesis phases using exposure time of sterilants (ethanol and sodium hypochlorite), antioxidant compounds (PVP, activated charcoal, Curcumin), plant growth regulators $(2,4-\mathrm{D}$ and $\mathrm{BA})$, and by changing light/ dark conditions was designed.

\section{Materials and Methods}

\section{The effect exposure times of Ethanol and home} bleach treatments

For this experiment, nodal segments were used as explants of S. junceum L. At first, semi hard woody and juvenile shoots were cut from stock plant. These were cleaned with one drop of washing-up liquid and then rinsed in tap water for $20 \mathrm{~min}$ to remove any dust or pests. In order to optimize disinfection and sterilization conditions, nodal segment explants were submerged in ethanol $70 \%$ for three periods $(0,30$ and $60 \mathrm{~s})$, then the explants were placed into commercial sodium hypochlorite $20 \%$ (home bleaching solution, containing $5 \%$ active agent) for three periods $(0,10$ and $15 \mathrm{~min})$. After disinfection process was completed, explants were cut into $0.5 \mathrm{~cm}$ segments and were cultured. The callogenesis culture medium MS used in this experiment was based on some plant growth regulators treatments containing $2 \mathrm{mg} \mathrm{L}^{-1} \mathrm{BA}, 0.5 \mathrm{mg} \mathrm{L}^{-1}$ IBA, $30 \mathrm{~g} \mathrm{~L}^{-1}$ sucrose and $7 \mathrm{~g} \mathrm{~L}^{-1}$ agar. The factors studied in this experiment included type and concentration of disinfectants (ethanol and home bleach) and the type of explants. It was a factorial experiment in a completely randomized design implemented with three replications for each treatment. After 7-10 days of culture, bacterial and fungal infections of any kinds and browning degree of explants were graded and recorded (Table 1 and Figure 1).

Table 1. The effect of Ethanol 70\% and home bleach $20 \%$ treatments at various exposure times on different types of contaminations in S. junceum nodal explants. Means followed by the same letters are not significantly different from each other $(p<0.01)$ as determined by Duncan's Multiple Range Test (DMRT).

\begin{tabular}{|c|c|c|c|}
\hline Ethanol 70\% (s) & Home Bleach $\mathbf{2 0 \%}(\mathbf{m i n})$ & Fungi infection & Bacterial infection \\
\hline 0 & 0 & $6^{\mathrm{d}}$ & $6^{\mathrm{e}}$ \\
\hline 0 & 10 & $3.33^{\mathrm{c}}$ & $1.66^{\mathrm{ab}}$ \\
\hline 0 & 15 & $3^{\mathrm{bc}}$ & $2.33^{\mathrm{cb}}$ \\
\hline 30 & 0 & $2^{\mathrm{ab}}$ & $3^{\mathrm{cd}}$ \\
\hline 30 & 10 & $1^{\mathrm{a}}$ & $2^{\mathrm{abc}}$ \\
\hline 30 & 15 & $1^{\mathrm{a}}$ & $1^{\mathrm{a}}$ \\
\hline 60 & 0 & $1^{\mathrm{a}}$ & $3.66^{\mathrm{a}}$ \\
\hline 60 & 10 & $1^{\mathrm{a}}$ & $1^{\mathrm{a}}$ \\
\hline 60 & 15 & $1^{\mathrm{a}}$ & $1.66^{\mathrm{ab}}$ \\
\hline
\end{tabular}



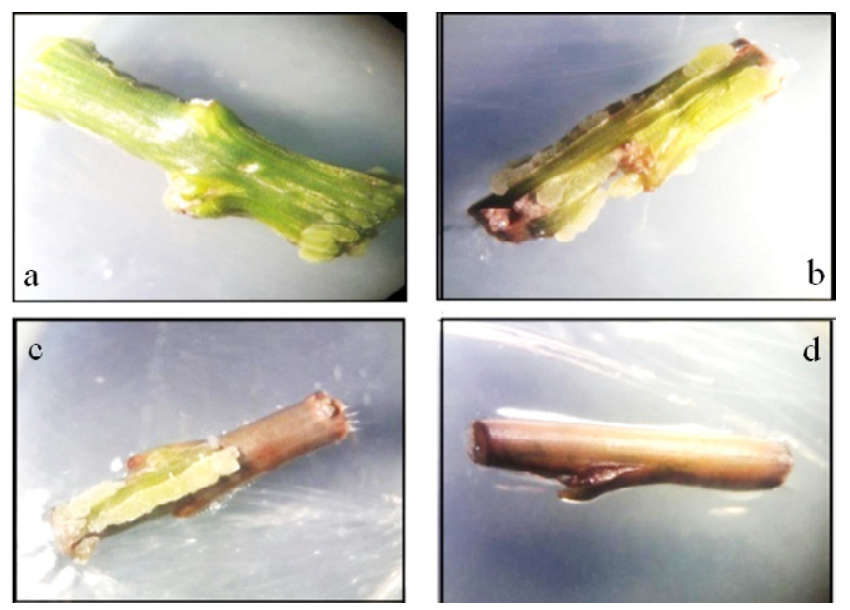

Figure 1. Browning ranking of nodal explants in S. junceum: (a) degree 0: no brown signs,

(b) degree 1: partial browning at the cut end, (c) level 2: browning at the cut end and bottom surface of the explant,

(d) level 5: Browning the whole surface of the explant

\section{The antioxidant treatments in initiation culture medium \\ Since browning phenomenon was occurred in explants after first experiment, this experiment was implemented. Here, the same semi hard woody shoots and nodal segments of $S$. junceum L. in $0.5 \mathrm{~cm}$ long were used as explants. At the beginning, explants were sterilized using alcohol $70 \%$ for $30 \mathrm{~s}$ and commercial sodium hypochlorite $20 \%$ concentration (home bleaching solution, containing $5 \%$ activated agent) for $15 \mathrm{~min}$. In all treatments, nodal segments were cultured on medium MS containing $0.5 \mathrm{mg}$ $\mathrm{L}^{-1} 2,4-\mathrm{D}, 30 \mathrm{~g} \mathrm{~L}^{-1}$ sucrose and $7 \mathrm{~g} \mathrm{~L}^{-1}$ agar. Antioxidant}

treatments for control browning of nodal explant in this experiment included submerging explants in solution PVP $0.5 \%$ for $0,20,30,60,120,240$, and $480 \mathrm{~min}$, rinsing explant in tap water for 30 and $60 \mathrm{~min}$, applying PVP $0.5 \%$ in media, curcumin (turmeric) $0.1 \%$ in media and activated charcoal $0.1 \%$ in culture medium. This experiment was implemented in a completely randomized design with three replications. The factors studied here were the type and the method of using antioxidants. Browning and fungal or bacterial infections and the amount of callogenesis were graded and recorded at the end of $1^{\text {th }}$ week and at the end of month 1, respectively (Table1, Figure 1 and 2).



a

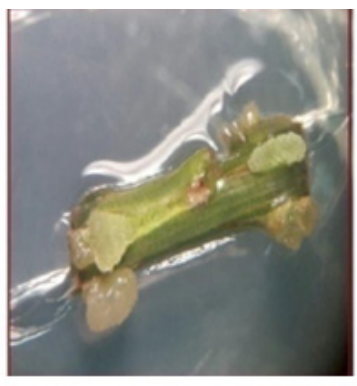

b

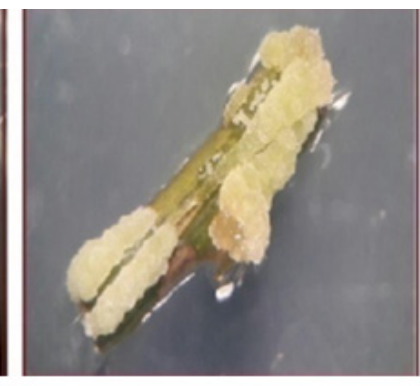

$\mathrm{c}$

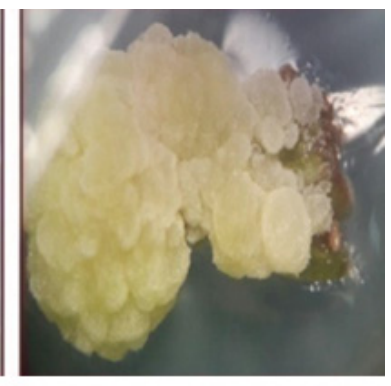

d

Figure 2. Callogenesis ranking of nodal explants in S. junceum: (a) No callogenesis, (b) Low, (c) Low to medium, (d) High

\section{The effects of PGR treatments and light condition}

In this experiment, the effect of light (16 hours' daylight and 8 hours' dark cycle) and continues darkness, and different concentrations of BA in combination with different concentrations of 2,4-D on callogenesis of nodal explants of $S$. junceum were studied. To this experiment, three concentrations of BA $\left(0,0.1\right.$ and $\left.0.2 \mathrm{mg} \mathrm{L}^{-1}\right)$ in combination with four concentrations of 2,4-D $(0,0.5,1.0$ and $2.0 \mathrm{mg} \mathrm{L}^{-1}$ ) were applied. The $500 \mathrm{mg} \mathrm{L}^{-1} \mathrm{PVP}$ was added to medium to prevent explants from browning.
Disinfected nodal explants (by ethanol $70 \%$ for $30 \mathrm{~s}$ and sodium hypochlorite $20 \%$ for $15 \mathrm{~min}$ ) were cut into $0.5 \mathrm{~cm}$ segments and cultured on callus induction medium. The cultures were kept at temperature $25 \pm 1{ }^{\circ} \mathrm{C}$ at light/dark and darkness conditions.

This experiment was carried out in factorial plan in completely randomized design with four replications. The results were evaluated every week and the time of callus initiation was recorded. At the end of $4^{\text {th }}$ week, callus induction percentage, the amount of callogenesis, texture 
and color of callus (callus morphology) and browning of explants were recorded. Browning degree and the amount of callogenesis in explants were evaluated according to grading represented in Figure 1 and 2.

\section{Results}

The effect exposure times of Ethanol and home bleach treatments

This experiment was scheduled to determine the most effective procedure for surface disinfection of explants by the way of identifying the best disinfectant and the best duration for explants to be exposed to them to control infections and browning disorder in S. junceum L.

The results from comparison of the mean interaction effects of ethanol duration and home bleach duration on the evaluated qualities in nodal explants showed that home bleach alone reduced the fungal infection to half in comparison with control explant, whereas ethanol duration alone (30 and $60 \mathrm{~s}$ ) showed better results in controlling fungal infection in nodal explant in comparison with control explants. The least fungal infection corresponded to simultaneous ethanol and home bleach treatment. However, there wasn't significant difference between each of treatments alone. Also, the results from comparison of means showed that the most bacterial infection was in control explants and then the ethanol treatment alone came after that. Once home bleach was applied alone, bacterial infection level reduced significantly compared with control treatment and didn't differ from combined simultaneous ethanol and home bleach treatment significantly, whereas it showed significant effect in comparison with ethanol alone. The least bacterial infection corresponded to applying combination of ethanol for $30 \mathrm{~s}$ and home bleach for $15 \mathrm{~min}$ (Table 1).

Studying the simple effects of different durations of alcohol treatment on browning degree of nodal explants showed that the highest degree of browning corresponded to applying ethanol for $60 \mathrm{~s}$ which didn't differ from control significantly, while the lowest degree was observed in ethanol treatment for 30s (Figure 3a). The results showed that applying home bleach for $10 \mathrm{~min}$ and $15 \mathrm{~min}$ increased browning degree in nodal explants. The browning increased significantly up to two times in 15 min treatment compared with control (Figure $3 b$ ).
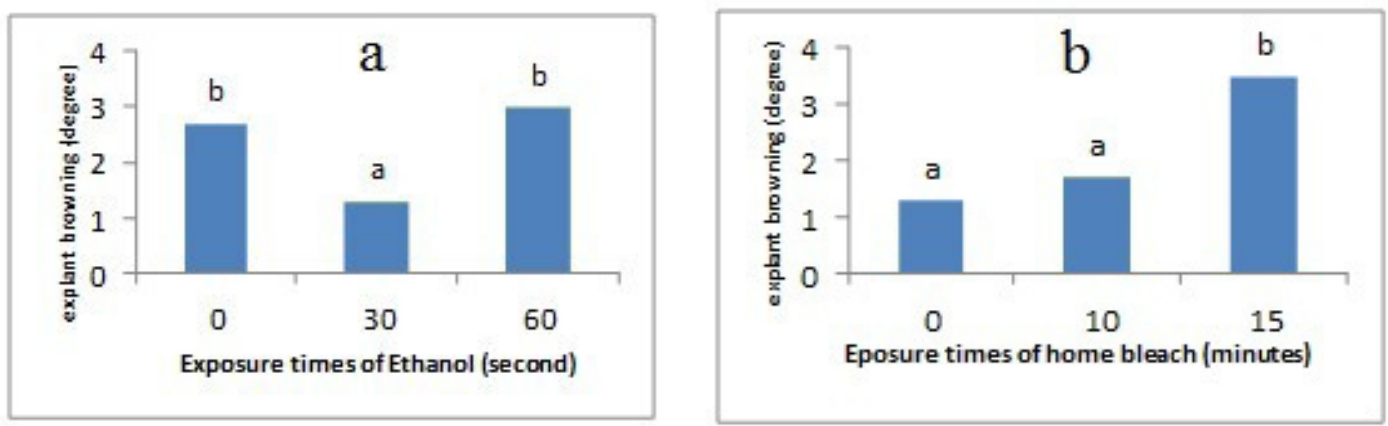

Figure 3. Influence of various exposure times sterilizing agents on $S$. junceum explant browning: (a): Home bleach 20\%, (b): Ethanol 70\%. Means followed by the same letters are not significantly different from each other $(\mathrm{p}<0.01)$ as determined by Duncan's Multiple Range Test (DMRT).

\section{Antioxidant treatments in initiation culture medium}

In all treatments, calluses initiated after 14 days of culture, in this study. The results showed that in pretreating explants with PVP $0.5 \%$ and most of treatments no bacterial infections were found, compared with control. Bacterial contamination just increased in some treatments such as pre-treating with PVP (240 and $480 \mathrm{~min}$ ). Furthermore, the effect of culture medium supplemented with PVP on explant browning was so significant that any tissue browning wasn't occurred in explants.

The highest browning sign (browning of the whole explant tissues) was occurred in control medium and in explants pre-treated with PVP (60, 240 and $480 \mathrm{~min})$ and in medium supplemented with curcumin. Also, to apply tap water (30 and $60 \mathrm{~min}$ ) increased the explant browning and there wasn't significant difference among these tap water treatments and curcumin treatment and PVP-soaked explant treatment (60, 120, 240 and 480 min). Adding activated charcoal to culture medium and soaking explants in PVP (20 and $30 \mathrm{~min}$ ) decreased browning in comparison with control which didn't differ significantly from application of PVP to medium, but they had significant difference with other treatments (Table 2). At the end of week 4, at first, the treatments injured due to infections were discarded then the extent of callus induction of remainder was evaluated. 
Table 2. Effect of antioxidant treatments on contamination, browning and callogenesis of survival of $S$. junceum nodal explants. Means followed by the same letters are not significantly different from each other $(p<0.01)$ as determined by Duncan's Multiple Range Test (DMRT).

\begin{tabular}{|c|c|c|c|}
\hline Antioxidant treatments & $\begin{array}{c}\text { Bacterial infection } \\
\text { (ranking) }\end{array}$ & $\begin{array}{c}\text { Explant browning } \\
\text { (ranking) }\end{array}$ & Callogenesis (ranking) \\
\hline Control & $1.00^{\mathrm{a}}$ & $5^{f}$ & Not survival \\
\hline Medium supplemented with $0.5 \%$ PVP & $1.00^{\mathrm{a}}$ & $0^{\text {a }}$ & $5^{\mathrm{a}}$ \\
\hline Explant immersed in $0.5 \%$ PVP (20min) & $1.00^{\mathrm{a}}$ & $2.26^{\mathrm{b}}$ & $4.26^{\mathrm{abc}}$ \\
\hline Explant immersed in $0.5 \%$ PVP (30min) & $1.00^{\mathrm{a}}$ & $2.13^{\mathrm{b}}$ & $3.37^{\mathrm{bc}}$ \\
\hline Explant immersed in $0.5 \%$ PVP (60min) & $1.00^{\mathrm{a}}$ & $4.13^{\text {def }}$ & $4.76^{\mathrm{ab}}$ \\
\hline Explant immersed in $0.5 \%$ PVP (120min) & $1.00^{\mathrm{a}}$ & $3.90^{\text {def }}$ & $3.50^{\mathrm{c}}$ \\
\hline Explant immersed in $0.5 \%$ PVP (240min) & $2.66^{\mathrm{b}}$ & $4.33^{\text {def }}$ & Not survival \\
\hline Explant immersed in $0.5 \%$ PVP (480min) & $3.00^{\mathrm{b}}$ & $4.73^{\text {ef }}$ & Not survival \\
\hline Medium supplemented with turmeric $0.1 \%$ & $1.00^{\mathrm{a}}$ & $4.20^{\text {def }}$ & $2.20^{\mathrm{d}}$ \\
\hline Medium supplemented with $0.1 \% \mathrm{AC}$ & $1.00^{\mathrm{a}}$ & $2.46^{\mathrm{bc}}$ & $3.33^{\mathrm{cd}}$ \\
\hline Running water (30 min) & $1.00^{\mathrm{a}}$ & $3.40^{\mathrm{cd}}$ & $3.20^{\mathrm{cd}}$ \\
\hline Running water (60 min) & $1.00^{\mathrm{a}}$ & $3.60^{\text {de }}$ & $3.26^{\mathrm{cd}}$ \\
\hline
\end{tabular}

The results from mean comparisons demonstrated that the greatest extent of callogenesis associated with application PVP to culture medium and soaking explants in PVP (20 and $60 \mathrm{~min}$ ), and it wasn't found significant difference between these three treatments, but application of PVP to medium differed significantly from other treatments. The lowest amount of callus was found in medium containing curcumin $1 \%$, compared with other treatments; however, there wasn't significant difference between curcumin treatment, tap water treatments and activated charcoal $1 \%$ treatment (Table 2 ).

The effects of PGR treatments and light conditions

In this experiment, all formed calluses had compact and hard textures, and were in light green (in presence of light) and in milky white color (under darkness). It wasn't found any callus formation in absence of plant growth regulators (control) or in culture medium supplemented with BA to alone either in presence or in absence of light. Callus initiation was occurred in all treatments containing 2,4-D. In culture medium supplemented with $0.5 \mathrm{mg} \mathrm{L}^{-1}$ 2,4-D in absence of BA, callus formation was initiated in 3 weeks in presence of light, and in 2 weeks under darkness conditions.

Calluses started to initiate after two weeks in culture medium supplemented with $0.5 \mathrm{mg} \mathrm{L}^{-1} 2,4-\mathrm{D}$ and 0.1 and $0.2 \mathrm{mg} \mathrm{L}^{-1} \mathrm{BA}$, under light and darkness conditions, while callus initiation time declined as 2,4-D concentration increased. So that in all treatments supplemented with 1 and $2 \mathrm{mg} \mathrm{L}^{-1} 2,4-\mathrm{D}$ alone or in combination with different concentration of BA, callus formation was observed just in one week of culture. It showed that there is a contrary link between concentration of 2,4-D and callus initiation time. It can be concluded based on comparison of means that 0.5 $\mathrm{mg} \mathrm{L}^{-1} 2,4-\mathrm{D}$ in combination with BA $(0,0.1$ and $0.2 \mathrm{mg}$ $\mathrm{L}^{-1}$ ) under darkness is the best PGR composition to get the maximum mass of callus.

Considering the results, the lowest level of 2,4-D $\left(0.5 \mathrm{mg} \mathrm{L}^{-1}\right)$ and BA $\left(0 \mathrm{mg} \mathrm{L}^{-1}\right)$ and darkness condition had appropriated the high callus mass, and used more concentrations of 2,4-D has reduced the mass of callus. The highest browning was obtained in medium supplemented with $2 \mathrm{mg} \mathrm{L}{ }^{-1} 2,4-\mathrm{D}$ and $0.2 \mathrm{mg} \mathrm{L}^{-1} \mathrm{BA}$ under darkness, while the least browning degree was obtained by used $0.5 \mathrm{mg} \mathrm{L}^{-1} 2,4-\mathrm{D}$ in medium and under darkness, so in most cases, low or zero concentration of 2,4-D had brought about least degree of browning in explants. It demonstrates that applying 2,4-D in low concentration alone or in combination with BA under both light and darkness conditions didn't have any influence on browning of explants, whereas browning degree increased either in presence or in absence of BA under both light and darkness conditions, as concentration of 2,4-D increased (Table 3). 
Table 3. Effect of PGR and treatments light conditions on Callogenesis and browning of nodal explants in S. junceum. Means followed by the same letters are not significantly different from each other $(p<0.01)$ as determined by Duncan's Multiple Range Test (DMRT).

\begin{tabular}{|c|c|c|c|c|c|}
\hline $\begin{array}{c}\text { 2,4-D } \\
\left(\mathrm{mg} \mathrm{L}^{-1}\right)\end{array}$ & $\begin{array}{c}\text { BA } \\
\left(m g \mathbf{L}^{-1}\right)\end{array}$ & $\begin{array}{c}\text { Treatment of light } \\
\text { regime }\end{array}$ & $\begin{array}{c}\text { Callus induction } \\
\text { time (week) }\end{array}$ & $\begin{array}{c}\text { Callogenesis } \\
\text { (ranking) }\end{array}$ & $\begin{array}{c}\text { Explant browning } \\
\text { (ranking) }\end{array}$ \\
\hline 0 & 0 & Light & $0^{d}$ & $0^{j}$ & $2.12^{\mathrm{efg}}$ \\
\hline 0 & 0 & Dark & $0^{d}$ & $0^{j}$ & $0.99^{c}$ \\
\hline 0 & 0.1 & Light & $0^{d}$ & $0^{\mathrm{j}}$ & $0.45^{\mathrm{abc}}$ \\
\hline 0 & 0.1 & Dark & $0^{d}$ & $0^{\mathrm{j}}$ & $0.36^{\mathrm{ab}}$ \\
\hline 0 & 0.2 & Light & $0^{d}$ & $0^{\mathrm{j}}$ & $0.29^{\mathrm{ab}}$ \\
\hline 0 & 0.2 & Dark & $0^{d}$ & $0^{j}$ & $0.07^{\mathrm{a}}$ \\
\hline 0.5 & 0 & Light & $3^{\mathrm{a}}$ & $4.24^{\mathrm{abc}}$ & $0.17^{\mathrm{ab}}$ \\
\hline 0.5 & 0 & Dark & $2^{b}$ & $4.57^{a}$ & $0.17^{\mathrm{ab}}$ \\
\hline 0.5 & 0.1 & Light & $2^{b}$ & $3.79^{\mathrm{cd}}$ & $0.31^{\mathrm{ab}}$ \\
\hline 0.5 & 0.1 & Dark & $2^{b}$ & $4.33^{\mathrm{ab}}$ & $0.37^{\mathrm{ab}}$ \\
\hline 0.5 & 0.2 & Light & $2^{b}$ & $2.74^{f}$ & $0.45^{\mathrm{abc}}$ \\
\hline 0.5 & 0.2 & Dark & $2^{b}$ & $4.24^{\mathrm{abc}}$ & $0.37^{\mathrm{ab}}$ \\
\hline 1 & 0 & Light & $1^{\mathrm{c}}$ & $3.16^{\mathrm{ef}}$ & $2.34^{\mathrm{fgh}}$ \\
\hline 1 & 0 & Dark & $1^{\mathrm{c}}$ & $3.99^{b c}$ & $0.99^{c}$ \\
\hline 1 & 0.1 & Light & $1^{\mathrm{c}}$ & $2.99^{f}$ & $1.66^{\mathrm{de}}$ \\
\hline 1 & 0.1 & Dark & $1^{\mathrm{c}}$ & $3.45^{\mathrm{de}}$ & $0.66^{b c}$ \\
\hline 1 & 0.2 & Light & $1^{\mathrm{c}}$ & $2.78^{f}$ & $1.52^{\mathrm{d}}$ \\
\hline 1 & 0.2 & Dark & $1^{\mathrm{c}}$ & $3.78^{\mathrm{cd}}$ & $0.66^{b c}$ \\
\hline 2 & 0 & Light & $1^{\mathrm{c}}$ & $1.62^{\text {ghi }}$ & $1.91 \mathrm{def}$ \\
\hline 2 & 0 & Dark & $1^{\mathrm{c}}$ & $1.83^{\mathrm{g}}$ & $1.77 \mathrm{de}$ \\
\hline 2 & 0.1 & Light & $1^{\mathrm{c}}$ & $1.70^{\mathrm{gh}}$ & $2.49^{\mathrm{gh}}$ \\
\hline 2 & 0.1 & Dark & $1^{\mathrm{c}}$ & $1.53^{\mathrm{ghi}}$ & $2.16^{\mathrm{efg}}$ \\
\hline 2 & 0.2 & Light & $1^{\mathrm{c}}$ & $1.28^{\mathrm{hi}}$ & $2.74^{\mathrm{h}}$ \\
\hline 2 & 0.2 & Dark & $1^{\mathrm{c}}$ & $1.24^{\mathrm{i}}$ & $3.48^{\mathrm{i}}$ \\
\hline
\end{tabular}

\section{Discussion}

One of the main restricting factors in micropropagation process, and especially in woody plants is a fungal and bacterial infection (Nazary Moghaddam Aghayeh et al., 2019). Death explants associated with infections was one of the limitations in initiation phase on nodal segment culture of $S$. junceum L. in present study, as in other woody plants. At disinfection phase, various chemical compounds are applied to control in vitro infections. However, some of them are less effective and some are too toxic for plants to apply in disinfection. So, it is difficult to adopt a standard disinfection method for all plants (Jan et al., 2013; Taghizadeh et al., 2016). The results from this experiment demonstrated that ethanol in combination with sodium hypochlorite had the best effect in control fungal infections for nodal explants of $S$. junceum $\mathrm{L}$.

It has been proven that two-phase disinfection method is beneficial for certain plant species. Ethanol usually exerts the influence in combination of sodium hypochlorite (Khanam and Chandra, 2017). In this study, it was found that sodium hypochlorite alone brought about reduction of bacterial infection, compared with ethanol alone. To apply ethanol for 30s simultaneously with sodium hypochlorite for 10 min was the best treatment for control bacterial infections in nodal explants. Ethanol may increase the efficiency of disinfection with sodium hypochlorite and other disinfectant by eliminating air bubble from surface of explants. Ethanol also improves penetration of disinfectants through the plant tissues by removing vaxes surface plant organs. During disinfection procedure, live material shouldn't lose their biological activity but just microorganisms should be eliminated. So, to sterilize explants, just disinfectant solutions in proper concentrations and with proper durations should be used (Putri et al., 2019).

Sodium hypochlorite as a bleaching substance is usually the main choice for surface disinfection. Because of toxic effects on explants, balance between concentrations and exposure durations should be determined experimentally for any explants (Putri et al., 2019). According to results of this study, ethanol and sodium hypochlorite were both effective for disinfecting nodal explants of $S$. junceum L. In Fragaria $\times$ ananassa hort., among treatments ethanol $70 \%$ for $30 \mathrm{~s}$ in combination with sodium hypochlorite for $(0,15$, $20 \mathrm{~min}$ ), the highest percentage of sterile cultures was achieved when nodal segments were treated with ethanol $70 \%$ for $30 \mathrm{~s}$ and sodium hypochlorite $1.5 \%$ for $20 \mathrm{~min}$, but viable explants percentage was less because of browning and injured status of tissues (Jan et al., 2013). 
Increase in the concentration of $\mathrm{NaOCl}$ and duration of immersion decreased the percentage of survival of explants taken Hevea brasiliensis (Moradpour et al., 2016). In this experiment, the highest nodal explant browning was achieved when sodium hypochlorite was applied alone for $15 \mathrm{~min}$ and ethanol was applied for $60 \mathrm{~s}$. This fact demonstrated that increased submerging duration in disinfectant solution gave rise to increase stress in tissues, and subsequently phenolic compounds would be produced. In Sour cherry (Prunus cerasus L.), by applying sodium hypochlorite $3 \%$ for $10 \mathrm{~min}$ and $1 \%$ for $20 \mathrm{~min}$, high viable explants were achieved (Mihaljevic et al., 2013).

In plant tissue culture, browning phenomenon and subsequently explant death is one of the main problems for initiation in woody plant culture, which is generally attributed to phenolic compounds (Hesami et al., 2020). Phenolic compounds brought about browning of nodal segments of $S$. junceum L. as they cultured in medium MS, which prevented $S$. junceum L. from callus initiation. Phenolic compounds could activate polyphenol oxidase enzyme and could alter cellular metabolism and then make brown precursor Quinine through oxidation. Quinine gradually penetrated explant tissues in culture medium, and therefore suppressed the activity of other enzymes which eventually caused compounds in medium to be toxic.

Antioxidants are able to suppress oxidation of phenolic compounds by changing oxidation potential of phenolic compounds explants, so they can decrease browning symptoms (Raj et al., 2020). Antioxidants are able to prevent phenolic compounds from oxidation, while the absorbents are able to absorb quinine (Nishchal et al., 2018). Many authors have reported some techniques to overcome phenolic compounds, including pre-soaking explants in tap water in order for phenolic compounds to get eliminated, adding antioxidants to culture medium, such as polyvinyl pyrrolidone (PVP) or activated charcoal which will cause elimination of phenols (Meziani et al., 2016). In present study, we succeeded to get free-infection cultures in all treatments, and bacterial infection was occurred just when the duration of pre-treatment with PVP was increased (240 and $480 \mathrm{~min}$ ).

Bacterial infection associated with increased duration of pre-treating with PVP solution (240 and 480min) might have caused by increased moisture to the greatest extent, which provided suitable conditions for growth of pathogens. No bacterial infection in other PVP-pretreated explants was observed because PVP was capable of reducing phenol leakage, and hence it supported preservation of high levels of phenolic compounds in explants to keep pathogens back from growing. In mango, significant reduction in infection extent was observed on explants treated with PVP (Krishna et al., 2008). In present study, it was found that applying PVP $0.5 \%$ to callogenesis culture medium of $S$. junceum L. prevented explants from browning. Similarly, in Curculigo latifolia, a medicinal plant, applying PVP $0.5 \%$ to culture medium reduced browning and infection in shoot-tip explants (Babaei et al., 2012).

Browning intensity increased as duration of soaking explants in PVP solution was increased. It might have been occurred as a result of undesirable effect of reduction of solution $\mathrm{pH}$ by antioxidants (Karantaca, 2008). In fact, limited leakage of phenolic compounds from tissue treated implies that viable explants rate is increased in culture duration. In Strelitzia reginae, soaking explants in citric acid (200 ppm) for 24 hours preceding culture in medium MS containing activated charcoal (1\%) decreased tissue browning effectively (Karantaca, 2008). In Cinnamomum tamala, phenolic compounds and other secondary compounds entered into the antioxidant solution when nodal explants and immature seeds were soaked in various antioxidant solutions immediately after harvest, but the explants got brown and damaged when they cultured without soaking in antioxidant solutions (Chitta et al., 2013).

The least browning was found in PVP treatments containing activated charcoal for 30 and $60 \mathrm{~min}$ in explant S. junceum L. It can be assumed that these treatments are capable of leakage phenols away from explant tissues effectively. The culture medium to supplemented with PVP to the better controlled browning disorder than to soak explants in PVP for 20 and $30 \mathrm{~min}$, and PVP in culture medium could make tissue browning disappeared, completely.

Activated charcoal absorbs both toxic phenolic compounds and growth regulators, so the amounts of activated charcoal should be reduced critically (Nayanakantha et al., 2010). In Saccharum officinarum L., medium MS supplemented with $0.2 \%$ and $0.3 \%$ PVP, $100 \%$ and $80 \%$ of explants had viable tissues respectively, while in medium containing $0.3 \%$ and $0.4 \%$ activated charcoal $46 \%$ and $40 \%$ of explants survived respectively (Shimelis et al., 2015). Activated charcoal made culture medium dark, and hence it didn't allow free radicals to form through oxidation of phenolic compounds (Nayanakantha et al., 2010). In this study, the most callogenesis was observed in medium containing $0.5 \%$ PVP, while the least callogenesis belonged to use of curcumin to the medium.

Antioxidant compounds can affect explants growing by the way of stimulating leaf expansion process; stimulating growing of callus, and promoting root development in cuttings (Huh et al., 2017). Therefore, the positive effect of PVP on callogenesis was related to absorb phenolic compounds out of explants. So, applying PVP to culture medium in concentration $0.5 \%$ can be reported as the treatment with lowest level of infections and with enough callus induction and as the best treatment for control browning in callogenesis medium of $S$. junceum L.

According to these results, it wasn't found any callus in free PGR medium and in medium supplemented with $\mathrm{BA}$ as well. This non-induction of callus might have caused by insufficient phyto-hormone in nodal explants of S. junceum L. needed for inducing. So, it is necessary to apply synthetic auxins, such as 2,4-D for stimulating callus induction (Budisantoso et al., 2017). The results from respective study showed that the existence of 2,4-D in low concentration was necessary for inducing callus formation in this shrub, even if there isn't any cytokinin in medium. The effective contribution of $2,4-\mathrm{D}$ to inducing callus 
formation was attributed to stimulates cell division in plant tissues and prevents tissues from organogenesis extremely (Shinta and Minarno, 2020). Maximum percentage of callus induction and the highest mass of callus was occurred in medium supplemented with $0.5 \mathrm{mg} \mathrm{L}^{-1} 2,4-\mathrm{D}$, with induction percentage and mass of callus were decreased as concentration of 2,4-D was increased. It showed that the concentration of auxin affected callogenesis in nodal explants of $S$. junceum L. differently. 2,4-D is widely applied either alone or in combination with cytokinin, specially BA, in order to stimulate in vitro callus induction. However, the combination and concentration of these plant growth regulators should be defined for species (Dawa et al., 2017) and efficiency of these reactions depends on species and tissue of the plant (Castro et al., 2016).

In case of Santalum album L. similar results were obtained, the most induction and growth of callus was occurred in medium containing low concentration of 2,4D (1.5 and $2.0 \mathrm{mg} \mathrm{L}^{-1}$ ) (Singh et al., 2016). The external application of BA either alone or in combination with 2,4$\mathrm{D}$ didn't have any influence on induction and growth of callus. It implied that cytokinin didn't have any positive or negative effect on growth of callus. Abdelmageed and colleages (2012) studied Michelia champaca L., and achieved similar results. It was found that darkness had positive effect on percentage of induction and growth of callus. Formation and growth of callus depended on culture conditions, such as light regimen, temperature, and composition of medium in terms of kind and concentration of PGR (Khan et al., 2018).

Abdi and Hedayati (2011) noted that in Delonix regia the most percentage of embryogenic callus formed from seeds and immature embryos was achieved by composition $2 \mathrm{mg} \mathrm{L} \mathrm{L}^{-1}$ 2,4-D and $0.25 \mathrm{mg} \mathrm{L}^{-1} \mathrm{BA}$ under darkness conditions. Ye et al. (2012) found that callus induction in leaf explants of Ziziphus jujube L. reached to $100 \%$ under darkness conditions, whereas under light conditions just $10 \%$ of leaves produced low-quality callus. This observation confirmed that callus induction is stimulated by darkness treatment. Similar results were obtained for Byrsonima verbascifolia L. The obtained results implied that decreased growth in presence of light might have caused by photodegradation of compounds in culture medium, including auxins (Erst et al., 2018).

Applying high concentration of 2,4-D led to increased browning of explant tissues, whereas nodal explants of $S$. junceum L. could produce callus without any browning in low 2,4-D concentration. 2,4-D is a strong auxin among others which is commonly used (Budisantoso et al., 2017). So, the negative effect of 2,4-D in high concentration on browning of nodal explants of $S$. junceum L. could be attributed to its high stability in media. Moreover, 2,4$\mathrm{D}$ have a relatively high mobility compared with other auxins, so it quickly accumulates in tissues and causes oxidation and degradation of them (Naz et al., 2018). These observations are consistent with those Kayani et al. (2008) had reported that callus got brown and damaged under high concentrations of auxine. According to these results, culture medium supplemented with $0.5 \mathrm{mg} \mathrm{L}^{-1} 2,4-$ $\mathrm{D}$ under darkness conditions can be proposed as the best callogenesis treatment in $S$. junceum $\mathrm{L}$.

\section{Conclusions}

In general, the results from this study showed that to apply ethanol $70 \%$ for 30 s and sodium hypochlorite $20 \%$ for $10 \mathrm{~min}$ is the best treatment for disinfection of nodal explants, because the least fungal and bacterial infections, the least explant browning degree. In order to lessen browning in nodal explants due to phenol discharge in conditions of in vitro culture, it is recommended that PVP $0.5 \%$ is applied internally to the culture medium because the least browning and the most callus mass were found in this treatment, compared with applying curcumin and activated charcoal to the medium and pre-treating by soaking explants in PVP and in running water. The best hormonal composition to induce callus from explants and get the highest amount of callus was $0.5 \mathrm{mg} \mathrm{L}^{-1}$ 2,4-D under darkness conditions. Although, induction of callus was occurred by applying 1.0 and $2.0 \mathrm{mg} \mathrm{L}^{-1} 2,4-\mathrm{D}$, calluses weren't able to proceed further because of getting brown. The existence of BA in applied concentration in this experiment didn't have any significantly effect on callogenesis. Therefore, the best concentration of 2,4-D $\left(0.5 \mathrm{mg} \mathrm{L}^{-1}\right)$ under darkness conditions is recommended to get callus from nodal explants of Spartium junceum L.

\section{Author Contribution}

MT: participated in all of experiments, coordinated the dataanalysis and contributed to the writing of the manuscript. MGD: Coordinated the laboratory work.

\section{Acknowledgments}

The authors are grateful to Arak University for supporting this work under research No: 94/4824.

\section{References}

ABDELMAGEED, A.H.A.; FARIDAH, Q.Z.; NOR SHUHADA, K.; JULIA, A.A. Callus induction and plant regeneration of Michelia champaca (Magnoliaceae): A multipurpose tree. Journal of Medicinal Plants Research, v.6, n.17, p.3338-3344, 2012. DOI: 10.5897/JMPR12.196

ABDI, G.H.; HEDAYAT, M. Induction of somatic embryogenesis from immature zygotic embryo and immature seed of royal poinciana (Delonix regia). World Applied Sciences Journal, v.13, n.3, p.391-395, 2011.

AL GHASHEEM, N.; STĂNICĂ, F.; PETICILĂ, A.G.; VENAT, O. In vitro effect of various sterilization techniques on peach (Prunus persica (L.) Batsch) explants. Scientific Papers, v.67, p.227-234, 2018. 
BABAEI, N.; ABDULLAH, N.A.P.; SALEH, G.H.; ABDULLAH, T.L. Control of contamination and explants browning in Curculigo latifolia in vitro cultures. Journal of Medicinal Plants Research, v.7, n.8, p.448-454, 2012. https://doi.org/10.5897/JMPR12.859

BUDISANTOSO, I.; AMALIA, N.; KAMSINAH, K. In vitro callus induction from leaf explants of Vanda $\mathrm{sp}$ stimulated by 2, 4-D. Biosaintifika: Journal of Biology \& Biology Education, v.9, n.3, p.492-497, 2017. DOI: 10.15294/biosaintifika.v9i3.11018

CASTRO, A.H.F.; BRAGA, K.D.Q.; SOUSA, F.M.D.; COIMBRA, M.C.; CHAGAS, R.C.R. Callus induction and bioactive phenolic compounds production from Byrsonima verbascifolia (L.) DC. (Malpighiaceae). Revista Ciência Agronômica, v.47, n.1, p.143-151, 2016. https://doi. org/10.5935/1806-6690.20160017.

CHITTA, R.D.; MADHABI, S.D.; SAKU- JAMIR, N. Callus mediated organogenesis and plant regeneration of Cinnamomum tamala nees. (Lauraceae) from leaf and zygotic embryos: International Journal of Pharma and Biosciences, v.4, n.1, p.614-622, 2013.

CLEMATISA, F.; VIGLIONEB, S.; BERUTOB, M.; LANZOTTIC, V.; DOLCID, P.; PONCETE, C.; CURIRA, $\mathrm{P}$. Endogenous isoflavone methylation correlates with the in vitro rooting phases of Spartium junceum L. (Leguminosae). Journal of Plant Physiology, v.171, p.1267-1275, 2014. https://doi.org/10.3389/fpls.2020.574557

DAWA, K.K.; EL-DENARY, M.E.; ABO-ELGLAGEL, I.M. Callus formation and shoot regeneration as affected by plant growth regulators and explant types in three strawberry cultivars (Fragaria x ananassa Duch.). Journal of Plant Production, v.8, n.5, p.599-604, 2017. https://doi. org/10.21608/JPP.2017.40481

ERST, A.A.; GORBUNOV, A.B.; ERST, A.S. Effect of concentration, method of auxin application and cultivation conditions on in vitro rooting of bog blueberry (Vaccinium uliginosum L.). Journal of Berry Research, v.8, n. 1, p.4153, 2018. https://doi.org/10.3233/JBR-170253

GAVILÁN, R.G.; SÁNCHEZ-MATA, D.; GAUDENCIO, M.; GUTIÉRREZ-GIRÓN, A.; VILCHES, B. Impact of the non-indigenous shrub species Spartium junceum (Fabaceae) on native vegetation in central Spain. Journal of Plant Ecology, v.9, n.2, p.132-143, 2016. https://doi. org/10.1093/jpe/rtv039

HESAMI, M.; TOHIDFAR, M.; ALIZADEH, M.; DANESHVAR, M.H. Effects of sodium nitroprusside on callus browning of Ficus religiosa: an important medicinal plant. Journal of Forestry Research, v.31, n.3, p.789-796, 2020. https://doi.org/10.1186/s13007-020-00655-9
JAN, A.; BHAT, K.M.; BHAT, S.J.A.; MIR, M.A.; BHAT, A.M.; IMTIYAZ, A.; WANI RATHER, J.A. Surface sterilization method for reducing microbial contamination of field grown strawberry explants intended for in vitro culture. African Journal of Biotechnology, v.12, n.39, p.57495753, 2013. https://doi.org/10.5897/AJB2013.12918

KARANTACA, J. Effect of antioxidant on in vitro establishment of Strelitzia reginae through shoot tip explants. Agrican Science, v.21, n.2, p.324-325, 2008.

KAYANI, S.; ZIA, M.; SARWAR, S.; RIAZ-URREHMAN, C.M.F. Callogenic studies of Achyranthes aspera leaf explant at different hormonal combinations. Pakistan Journal of Biology Science, v.11, n.6, p.950952, 2008. https://doi.org/10.3923/pjbs.2008.950.952

KHAN, T.; ABBASI, B.H.; KHAN, M.A. The interplay between light, plant growth regulators and elicitors on growth and secondary metabolism in cell cultures of Fagonia indica. Journal of Photochemistry and Photobiology Biology, v.185, p.153-160, 2018. https://doi. org/10.1016/j.jphotobiol.2018.06.002

KHANAM, B.; CHANDRA, R. Optimization of surface sterilization process of selected dye-yielding plants for isolation of bacterial endophytes. In: MUKHOPADHYAY, K.; SACHAN, A.; KUMAR, M. (eds). Applications of biotechnology for sustainable development. Singapore: Springer, 2017. p.45-50.

KRISHNA, H.; SAIRAM, R.; SINGH, S.; PATEL, V.; SHARMA, R.; GROVER, M.; NAIN, L.; SACHDEV, A. Mango explant browning: Effect of ontogenic age, mycorrhization and pre-treatments. Scientia Horticulture, v.118, p.132-138, 2008. https://doi.org/10.21273/ HORTSCI12987-18

MAHMOUD, S.N.; AL-ANI, N.K. Effect of different sterilization methods on contamination and viability of nodal segments of Cestrum nocturnum L. International Journal of Research Studies in Biosciences, v.4, n.1, p.49, 2016. https://doi.org/10.20431/2349-0365.0401002

HUH, Y.S.; LEE, J.K.; NAM, S.Y. Effect of plant growth regulators and antioxidants on in vitro plant regeneration and callus induction from leaf explants of purple passion fruit (Passiflora edulis Sims). Journal of Plant Biotechnology, v.44, n.3, p.335-342, 2017. https://doi. org/10.5010/JPB.2017.44.3.335

MEZIANI, R.; JAITI, F.; MAZRI, M.A.; HASSANI, A.; SALEM, S.B.; ANJARNE, M.; ALEM, C. Organogenesis of Phoenix dactylifera L. cv. Mejhoul: Influences of natural and synthetic compounds on tissue browning, and analysis of protein concentrations and peroxidase activity in explants. Scientia Horticulturae, v.204, p.145-152, 2016. https://doi.org/10.1016/j.scienta.2016.04.009 
MIHALJEVIC, I.; DUGALIC, K.; TOMAS, V.; VILJEVAC, M.; PRANJIC, A.; CMELIK, Z.; PUSKAR, B.; JURKOVIC, Z. In vitro sterilization procedures for micropropagation of 'oblacinska' sour cherry: Journal of Agricultural Sciences, v.58, p.117-126, 2013. https://doi. org/10.2298/JAS1302117M

MOMENI, M.E. GANJI-MOGHADAM, A.; ASGHARZADEH, H.; KAZEMZADEH-BENEH. Micropropagation of juniper (Juniperus polycarpos): optimizing surface sterilization pretreatments can play key role in suppression of contamination and browning of shoot tip explants. Azarian Journal of Agriculture, v.4, n.5, p.169-175, 2017.

MORADPOUR, M.; AZIZ, M.A.; ABDULLAH, S.N.A. Establishment of in vitro culture of rubber (Hevea brasiliensis) from field-derived explants: effective role of silver nanoparticles in reducing contamination and browning. Journal of Nanomedicine and Nanotechnology, v.7, n.375, p.2, 2016. https://doi. org/10.4172/2157-7439.1000375

NAYANAKANTHA, N.M.C.; SINGH, B.R.; KUMAR, A. Improved culture medium for micropropagation of Aloe vera L. Tropical Agricultural Research and Extention, v.13, n.4, p.87-93, 2010. https://doi.org/10.4038/tare. v13i4.3291

NAZ, S.; SIDDIQUILAND, M.F.; RAZA, S. Effect of different growth regulators on in vitro propagation of Brassica napus L. Pakistan Journal of Botany, v.50, n.5, p.1871-1876, 2018.

NAZARY MOGHADDAM AGHAYEH, R.; ABEDY, B.; BALANDARI, A.; SAMIEI, L.; TEHRANIFAR, A. Contamination control in Iranian seedless barberry micropropagation. Journal of Plant Physiology and Breeding, v.9, n.1, p.97-110, 2019.

NISHCHAL, N.; MIR, H.; RANI, R.; PAL, A.K. Effect of antioxidants in controlling phenol exudation in micropropagation of Litchi cv. Purbi. Current Journal of Applied Science and Technology, p.1-7, 2018. https://doi. org/10.9734/CJAST/2018/45992

PUTRI, A.I.; HARYJANTO, L.; HERAWAN, T.; FAUZI, A.; IZUDIN, E.; SETIAWAN, A.; WAHNO, I. Effect of methylisothiazolinone biocide in tissue culture sterilization of Casuarina equisetifolia. IOP Conference Series: Earth and Environmental Science, v.522, n.1, p.012008, 2020. https://doi.org/10.1088/1755-1315/522/1/012008
RAJ, P.; JAKHAR, M.L.; AHMAD, S.; CHAHAR, S.; JAT, K.Y.M.H.R. A study on effects of antioxidants in micropropagation of Bael (Aegle marmelos L.). Journal of Pharmacognosy and Phytochemistry, v.9, n.1, p.16871690,2020 .

RANJAN, T.; SAHNI, S.; PRASAD, B.D.; KUMAR, R.R.; RAJANI, K.; JHA, V.K.; SHARMA, V.; KUMAR, M.; KUMAR, V. Sterilization Technique. In: PRASAD, B.D.; SAHNI, S.; KUMAR, P.; SIDDIQUI, M.W. Plant Biotechnology. New York: Apple Academic Press, 2017. p.69-86.

SHIMELIS, D.; BANTTE, K.; FEYISSA, T. Effects of polyvinyl pyrrolidone and activated charcoal to control effect of phenolic oxidation on in vitro culture establishment stage of micropropagation of sugarcane (Saccharum officinarum L.). Advances in Crop Science and Technology, v.3, p.184, 2015. https://doi.org/10.4172/2329-8863.1000184

SHINTA, S.; MINARNO, E.B. In vitro embryogenic callus induction of Carica pubescens Lenne \& K. Koch using 2,4-D (2,4-dichlorophenoxy acetic acid) and BAP (6-benzylaminopurin). Berkala Penelitian Hayati Journal of Biological Researches, v.25, n.2, p.38-44, 2020. https://doi.org/10.23869/bphjbr.25.2.20205

SINGH, C.K.; RAJ, S.R.; JAISWAL, P.S.; PATIL, V.R.; PUNWAR, B.S.; CHAVDA, J.C.; SUBHASH, N. Effect of plant growth regulators on in vitro plant regeneration of sandalwood (Santalum album L.) via organogenesis. Agroforestry Systems, v.90, n.2, p.281-288, 2016. https:// doi.org/10.1007/s10457-015-9853-3

TAGHIZADEH, M.; SOLGI, M.; SHAHRJERDI, I. Essential oil as an alternative to chemical antimicrobial agent for the culture of strawberry in vitro. Journal of Horticulture, Forestry and Biotechnology, v.20, n.4, p.99-106, 2016.

YE, X.; CHEN, Y.; LI, J.; YU, X.; FENG, F.; ZHENG, $Z$. Callus induction and adventitious shoot regeneration in Zizyphus jujuba Mill. 'Huizao'. African Journal of Biotechnology, v.11, n.16, p.3888-3894, 2012. https://doi. org/10.5897/AJB11.234 